\title{
ANALISIS MUTU LEMBAGA PENDIDIKAN BERDASARKAN FUNGSI MANAJEMEN DI PONDOK PESANTREN THAWALIB PADANG SUMATERA BARAT
}

\author{
Yusutria \\ STKIP PGRI Sumatera Barat \\ Jln. Gn. Pangilun, Gn. Pangilun, Padang Utara, \\ Kota Padang, Sumatera Barat 25173 \\ Email: yusutriayusut@ymail.com \\ DOI: $10.29313 /$ tjpi.v7i2.3833 \\ Accepted: Agust 10th, 2018. Approved: April 9th, 2019. Published: April 9th, 2019
}

\begin{abstract}
This study aims to reveal the analysis of management functions in the educational institutions of the Thawalib Padang Islamic Boarding School in order to improve the quality of Islamic boarding school education. The research method used is descriptive analytical with a qualitative approach. The results of the study show: 1). Based on planning and decision making (planning) in formulating a vision, mission and objectives as well as a clear and achieved curriculum; 2) Based on organizing which already has a clear organizational structure starting from the foundation of the institution along with its staff, the leadership of the pesantren and its staff, the school and the staff of the teacher and the education staff and the school committee; 3) Based on clear (leading) leadership. Should the leadership in an educational institution not be a double function or double position. In order to facilitate control and control; and 4) Based on control (controlling). Control is carried out regularly. This is done with the aim not to look for mistakes or shortcomings but for the sake of good going forward.
\end{abstract}

Keywords: Agency Quality, Management Function.

\section{ABSTRAK}

Penelitian ini bertujuan mengungkap analisis fungsi manejemen pada lembaga pendidikan Pondok Pesantren Thawalib Padang dalam rangka meningkatkan mutu pendidikan pesantren. Metode penelitian yang digunakan adalah deskriptif analitis dengan pendekatan kualitatif. Hasil penelitian menunjuk.kan: 1). Berdasarkan perencanaan dan pengambilan keputusan (planning) dalam merumuskan visi, misi dan tujuan serta kurikulum yang jelas dan dicapai; 2) Berdasarkan pengorganisasian (organizing) yang telah memiliki struktur organsasi yang jelas mulai dari yayasan lembaga beserta jajarannya, pimpinan pesantren beserta jajarannya, sekolah beserta staff guru dan tenaga kependidikannya serta komite sekolab; 3) Berdasarkan kepemimpinan (leading) yang jelas. Hendaknya dalam kepemimpinan yang ada dalam lembaga pendidikan jangan sampai ada double fungsi atau rangkap jabatan. Agar mempermudah pengendalian dan pengontrolan; dan 4) Berdasarkan pengendalian (controlling). Dilakukannya pengendalian/pengontrolan secara berkala. Hal tersebut dilakukan dengan tujuan bukan untuk mencari kesalahan/kekurangan akan tetapi demi untuk kebaikan kedepannya.

Kata Kunci: Mutu Lembaga, Fungsi Manajemen. 


\section{PENDAHULUAN}

Pendidikan merupakan suatu hal yang sangat esensial di dalam kehidupan manusia karena melalui pendidikan manusia diatur tentang bagaimana cara beribadah kepada Allah SWT, bermuamalah dengan sesama manusia, dan bagaimana cara berakhlak yang baik. Pendidikan menjadi dasar yang sangat penting karena melalui pendidikan manusia bisa memperhatikan dan melihat, menggunakan serta mengelola segala ciptaan Allah SWT yang ada di langit dan di bumi dengan baik. (Yusutria, 2016: 1).

Pendidikan merupakan pondasi penting dalam pembangunan kepribadian dan peradaban kemanusiaan. Memperhatikan sejarah, maka dunia pendidikan mengalami perkembangannya secara dinamis, mulai dari materi pelajaran, sistem pembelajaran, hingga manajemen pengelolaan. Untuk menjadikan pendidikan tersebut bermutu. Pendidikan yang bermutu adalah pendidikan yang mampu memenuhi harapan dan mampu memenuhi keinginkan dan kebutuhan masyarakat,untuk mewujutkan harapan masyarakat,sekolah dan guru harus mempunyai harapan yang tinggi terhadap siswa. (Amrullah Aziz. 2015 :2).

Institusi pendidikan tertua di Indonesia adalah pesantren. Banyak ahli mengemukakan bahwa pesantren merupakan salah satu institusi pendidikan yang terpenting dan tertua di Indonesia yang bergerak di bidang pengembangan pengetahuan keagamaan Islam. Sebelum Belanda datang. Lembaga pendidikan tipe pesantren telah terlebih dahulu berdiri di tanah nusantara. (Endang. 2008: 78).

Tipe ideal model pendidikan pondok pesantren yang banyak dikembangkan saat sekarang ini adalah tipe integral antara sistem pendidikan klasik dan sistem pendidikan modern. Pengembangan tipe ideal ini tidak akan merubah total wajah dan keunikan sistem pendidikan pesantren menjadi sebuah model pendidikn umum yang cenderung reduksionistik terhadap nilai-nilai yang terkandung dalam sistem pendidikan pondok pesantren (Sulthon Masyhud, 2003: 14).

Pondok pesantren berarti suatu lembaga pendidikan dan pengajaran agama Islam yang pada umumnya pendidikan dan pengajarannya diberikan dengan metode non klasikal. Kehadiran pesantren di tengah-tengah masyarakat tidak hanya sebagai lembaga pendidikan saja, tetapi juga sebagai lembaga penyiaran agama dan sosial keagamaan. (Rodliyah, 2014: 301). Pondok pesantren merupakan salah satu lembaga pendidikan tradisional yang dalam kesehariannya mempelajari, memahami, mendalami, menghayati dan mengamalkan ajaran maupun nilai-nilai Islam dengan menitikberatkan pada urgensi moral keagamaan sebagai pedoman perilaku sehari-hari. (Mastuhu. 1994: 55).

Tercapainya tujuan akan suatu lembaga pendidikan pesantren tersebut dalam menitikberatkan pada urgensi moral keagamaan sebagai pedoman perilaku sehari-hari dibutuhkan konsep manajemen yang solid, diantaranya ada empat fungsi dasar manajerial, yaitu perencanaan dan pengambilan keputusan (planning), pengorganisasian (organizing), kepemimpinan (leading), dan pengendalian (controlling) merupakan upaya terstruktur yang mesti ada dalam rangka pembenahan dan pengembangan tubuh pesantren.

Hal ini sesuai dengan pendapat Malik Fajar mengatakan bahwa jika ingin menatap masa depan Pendidikan Islam di Indonesia yang mampu memainkan peran strategis bagi kemajuan umat dan bangsa, perlu ada keterbukaan wawasan dan keberanian dalam memecahkan hal yang mendasar, yaitu: kejelasan antara yang dicita-citakan dengan langkah-langkah operasional, penguatan di bidang sistem kelembagaan, perbaikan atau pembaharuan pengelolaannya atau manajemennya. (A. Malik Fadjar. 1999: 21).

Diantara lembaga pendidikan Pondok Pesantren itu adalah Pondok 
Pesantren Thawalib Padang Sumatera Barat yang berlokasi di kota Padang dengan visi: "Disiplin, Cerdas, Terampil Dan Berakhlak Mulia Sesuai Al-Qur'an Dan Sunnah". Agar lembaga tersebut dapat menatap masa depan dan mampu memainkan peran strategis bagi kemajuan umat dan bangsa, perlu ada keterbukaan wawasan dan keberanian dalam memecahkan hal yang mendasar dibutuhkan konsep manajemen yang solid, diantaranya ada empat fungsi dasar manajerial, yaitu perencanaan dan pengambilan keputusan (planning), pengorganisasian (organizing), kepemimpinan (leading), dan pengendalian (controlling) merupakan upaya terstruktur yang mesti ada dalam rangka pembenahan dan pengembangan tubuh pesantren, sebagaimana yang dijelaskan oleh Malik Fajar.

\section{METODE PENELITIAN}

Pada penelitian ini menggunakan pendekatan kualitatif yang bersifat naturalistik dalam memahami makna yang mendasari tingkah laku partisipan, mendiskripsikan latar interaksi yang kompleks, eksplorasi untuk mengidentifikasi tipe-tipe informasi, mendeskripsikan fenomena penelitian ini menggunakan pendekatan kualitatif, untuk memahami makna yang mendasari tingkah laku partisipan, mendiskripsikan latar interaksi yang kompleks, eksplorasi untuk mengidentifikasi tipe-tipe informasi, mendeskripsikan fenomena (Sanipah Faisah, 1990: 22). Data dikumpulkan dari latar yang alami (natural setting) sebagai sumber data langsung.

Hal ini memungkinkan peneliti menemukan local wisdom (kearifan local), traditional wisdom (kearifan tradisi), moral value (emik, etik dan noetik) dan teori dari subyek yang diteliti. Teknik pengumpulan data yakni wawancara (depth interview), pengamatan (observation) dan studi dokumentasi.

\section{TINJAUAN PUSTAKA}

\section{Pendidikan Pondok Pesantren}

Pesantren merupakan suatu lembaga pendidikan Islam yang melembaga di Indonesia, dimana kyai dan santri (guru dan murid) hidup bersama dalam suatu asrama yang memiliki bilik-bilik kamar sebagai ciriciri esensialnya dengan berdasarkan nilai agama Islam. Pondok pesantren mempunyai lima elemen dasar yaitu pondok, mesjid, pengajaran kitab-kitab klasik Islam, santri dan kyai. Kelima elemen tersebut merupakan elemen dasar yang dimiliki sebuah pesantren. Pesantren dikatakan lengkap apabila telah memiliki kelima elemen tersebut di atas dan masing-masing mempunyai fungsi tersendiri dalam pembinaan santri melalui kegiatan-kegiatan yang diselenggarakan baik dalam bidang fisik maupun mental santri di pondok pesantren.

Pondok Pesantren yang merupakan intitusi lembaga pendidikan Islam pertama dan sudah lama mengakar dalam sejarah pendidikan Indonesia, bahkan model pondok pesantren telah dijadikan contoh bagi negara-negara lain. Sebagai intitusi pendidikan Islam tradisional pesantren telah banyak memberikan masukkan bagi upaya mewujudkan idealisme pendidikan nasional yang bukan hanya meningkatkan kualitas sumber daya manusia pada aspek penguasaan sains melainkan mencetak warga negara Indonesia yang memiliki ketaqwaan terutama dalam memupuk generasi yang berakhlak karimah.

Pondok pesantren merupakan suatu lembaga pendidikan dimana kyai dan santri (guru dan perserta didik) hidup bersama dalam suatu komplek dan memiliki asrama atau bilik-bilik kamar sebagai ciri esensialnya, dengan berlandaskan nilai agama Islam. Pondok pesantren merupakan "lembaga pendidikan tradisonal Islam dengan menekankan pentingnya moral agama sebagai pedoman perilaku santri sehari-hari, serta menekankan pentingnya 
moral keagamaan tersebut dalam menjalani hidup bermasyarakat nanti." (Depag RI, 2002: 3).

Pondok pesantren merupakan suatu lembaga pendidikan Islam dengan menetap dalam asrama (pondok) dengan seorang kyai, tuan guru sebagai tokoh utama dan mesjid sebagai pusat lembaga dan menampung peserta didik (santri), yang belajar untuk memperdalami suatu ilmu agama Islam. (Yusutria, 2006: 25).

\section{Manajemen Pendidikan}

Manajemen sebagai suatu proses melihat bagaimana cara orang untuk mencapai suatu tujuan yang telah ditetapkan terlebih dahulu. Pengertian ini merujuk kepada Griffin bahwa manajemen adalah suatu rangkaian aktivitas yang diarahkan pada berbagai sumber daya organisasi yang ada dengan maksud untuk mencapai tujuan organisasi secara efektif dan efisien. (M. Thoriq Nurmadiansyah. 2016: 102).

Dalam kaitannya dengan manajemen, seorang manajer menurut Griffin bertanggung jawab mengkombinasikan, mengkoordinasikan, dan menggerakkan berbagai sumber daya tersebut untuk mencapai tuuan organisasi. Pengkombinasian, pengkoordinasian, dan penggerakkan sumber daya tersebut dilakukan oleh manajer melalui fungsifungsi dan aktivitas manajerial dasar. Griffin mengemukakan empat fungsi dasar manajerial, yaitu: perencanaan dan pengambilan keputusan (planning and decision making), pengorganisasian (organizing), kepemimpinan (leading), dan pengendalian (controlling). (Ensiklopedi Ekonomi Bisnis dan Manajemen. 1992 : 374).

Manajemen pendidikan merupakan proses manajemen dalam pelaksanaan tugas pendidikan dengan mendayagunakan segala sumber secara efesien untuk mencapai tujuan secara efektif. (Muhammad Nur. 2016: 95). Manajemen pendidikan dengan menggunakan istilah administrasi pendidikan yang diartikan sebagai keseluruhan proses kerjasama dengan memanfaatkan semua sumber personil dan materil yang tersedia dan sesuai untuk mencapai tujuan pendidikan yang telah ditetapkan secara efektif dan efisien. (Muradi (ed.), 2013: 116).

Mujammil Qomar mengatakan bahwa manajemen pendidikan Islam adalah suatu proses pengelolaan lembaga pendidikan Islam secara Islami dengan cara menyiasati sumber-sumber belajar dan halhal lainyang terkait untuk mencapai tujuan pendidikan Islam secara efektif dan efisien. (Mujammil Qomar. 2007: 1).

Suatu lembaga pendidikan pesantren dalam menitikberatkan pada urgensi moral keagamaan sebagai pedoman perilaku sehari-hari dibutuhkan konsep manajemen yang solid, diantaranya ada empat fungsi dasar manajerial, yaitu perencanaan dan pengambilan keputusan (planning), pengorganisasian (organizing), kepemimpinan (leading), dan pengendalian (controlling) merupakan upaya terstruktur yang mesti ada dalam rangka pembenahan dan pengembangan tubuh pesantren.

Hal ini sesuai dengan pendapat Malik Fajar mengatakan bahwa jika ingin menatap masa depan Pendidikan Islam di Indonesia yang mampu memainkan peran strategis bagi kemajuan umat dan bangsa, perlu ada keterbukaan wawasan dan keberanian dalam memecahkan hal yang mendasar, yaitu: kejelasan antara yang dicita-citakan dengan langkah-langkah operasional, penguatan di bidang sistem kelembagaan, perbaikan atau pembaharuan pengelolaannya atau manajemennya. (A. Malik Fadjar. 1999: 21).

Pengembangan strategi manajemen pendidikan sangatlah penting bagi peningkatan mutu pendidikan. Hal ini dikarenakan banyaknya tuntutan yang harus dipenuhi oleh manusia dan semakin kompleksnya kehidupan. Dari sini, maka diperlukan pola-pola dan kiat-kiat manajemen pendidikan supaya dapat menjawab tuntutan tersebut. Dikatakan oleh Soekarno K. (1965: 41-42), bahwa 
manajemen dapat mencapai tujuan sebaikbaiknya, sangatlah diperlukan adanya tools (sarana, alat dan unsur manajemen).

Alat-alat manajemen pendidikan adalah: Men yaitu tenaga manusia digerakkan; Money adalah dana yang diperlukan untuk mencapainya; Methods merupakan cara/sistem untuk mencapai tujuan; Material atau bahan-bahan sebagai sumberdaya pendidikan yang mencapai tujuan pendidikan; Machines yang diperlukan; dan Market atau pasaran, tempat untuk melempar hasil produksi. (Soekarno, K.. 1965:41-42).

Seorang manajer bertugas memadukan sumber-sumber pendidikan secara keseluruhan dan mengontrol/mengawasi agar sesuai dengan tujuan pendidikan. Manajemen sebagai suatu sistem harus meliputi dimensi-dimensi manajeman berdasarkan sasaran (Management by Objective), manajemen pada aspek struktur, manajemen pada aspek teknik, manajeman pada aspek pesonalia, manajemen pada aspek informasi. (Yusutria. 2012: 2).

\section{HASIL DAN PEMBAHASAN}

\section{Implementasi Manajemen dalam Meningkatkan Mutu Pendidikan di Pondok Pesantren Thawalib Padang.}

Penerapan manajemen dalam meningkatkan mutu pendidikan di Pondok Pesantren Thawalib Padang dapat dipahami dari hal-hal berikut.

Berdasarkan Perencanaan dan Pengambilan Keputusan (Planning) dalam merumuskan visi, misi dan tujuan yang dicapai pada table 1 .
Tabel. 1. Visi, Misi dan Tujuan Sekolah

\begin{tabular}{|c|c|}
\hline Tisi & $\begin{array}{l}\text { disiplin, cerdas, terampil dan } \\
\text { berakhlak mulia sesuai al- } \\
\text { quran dan sunnah }\end{array}$ \\
\hline \multirow[t]{8}{*}{ Misi } & Menyelenggarakan Pendidikan \\
\hline & $\begin{array}{l}\text { dasar dan Menengah yang } \\
\text { bercirikan Islam }\end{array}$ \\
\hline & Melaksanakan Proses Belajar \\
\hline & $\begin{array}{l}\text { Mengajar dengan Bimbingan yang } \\
\text { efektif }\end{array}$ \\
\hline & $\begin{array}{l}\text { Menumbuh kembangkan budaya } \\
\text { disiplin bagi seluruh warga } \\
\text { madrasah }\end{array}$ \\
\hline & $\begin{array}{l}\text { Membudayakan akhlak mulia bagi } \\
\text { seluruh warga masyarakat }\end{array}$ \\
\hline & $\begin{array}{lll}\text { Membina life skill yang } \\
\text { terprogram untuk } & \text { menghadapi } \\
\text { tantangan zaman } & \end{array}$ \\
\hline & $\begin{array}{l}\text { Membudayakan disiplin bagi } \\
\text { seluruh warga Thawalib Padang }\end{array}$ \\
\hline Tujuan & $\begin{array}{l}\text { Tujuan madrasah sebagai bagian } \\
\text { dari tujuan pendidikan nasional } \\
\text { adalah meningkatkan kecerdasan, } \\
\text { pengetahuan, kepribadian, } \\
\text { berakhlaqul karimah }\end{array}$ \\
\hline
\end{tabular}

Visi dan misi serta tujuan yang dimiliki oleh pondok pesantren tersebut didukung dengan dua kurikulum, baik kurikulum yang berasal dari depaq dan kurikulum pesantren yang disesuaikan dengan kurikulum muatan lokal. Kurikulum tersebut juga diiringi dengan berbagai macam program kegiatan ektrakurikuler diantaranya pramuka, pencak silat, pidato tiga bahasa, menjahit, olah raga. Kurikulum yang berasal dari Depaq disesuaikan dengan kebijakan yang dikeluarkan oleh Depaq, sementara kurikulum pondok pesantren harus dibicarakan kepada pimpinan pondok pesantren dulu dan guru yang akan menyajarkannya.

Berdasarkan Pengorganisasian (Organizing) Pondok Pesantren Thawalib Padang memiliki struktur organsasi yang jelas. Pondok Pesantren Thawalib berada di bawah yayasan yaitu Yayasan Pendidikan Thawalib Padang. Yasasan tersebut juga memiliki struktur organisasi yang terdiri dari 
Pembina (Ketua, wakil ketua, sekretaris, wakil sekretaris, anggota Pembina) dan Pengurus Yayasan yang terdiri dari Ketua Umum, Ketua I, Ketua II, Sekretaris Umum, Sekretaris I, Sekretaris II, Bendahara dan Pengawas. Sementara Pondok Pesantren Thawalib ini di pimpin oleh seorang pimpinan pondok, pengasuh santri, wali kamar, organisasi santri dengan nama OSTP (Organisasi Santri Thawalib Padang). Adapun sekolah dikepalai oleh kepala madrasah, wakil bidang kurikulum, wakil bidang kesiswaan, dan kepala tata usaha. Madrasah yang ada baru Madrasah Tsanawiyah/setingkat dengan SMP. Pondok Pesantren Thawalib Padang juga mempunyai komite sekolah, sekretaris komite dan bendahara komite sekolah.

Kesimpulannya bahwa di lembaga ada tiga struktur organisasi yang sangat bertanggungjawab terhadap lembaga pendidikan ini yaitu; Yayasan, Pondok Pesantren, Madrasah. Bermutunya suatu lembaga pendidikan didukung dari berbagai unsur baik dari internal maupun dari ekternal.

Sebagaimana diungkapkan oleh Muhammad Fadhli, bahwa mutu lembaga pendidikan berbagai macam dukungan, diantaranya; 1) dukungan dari pemerintah, 2) Kepemimpinan Kepala sekolah yang efektif, 3) Kinerja guru yang baik, 4) kurikulum yang relevan, 5) lulusan yang berkualitas, 6) budaya dan iklim organisasi yang efektif, 7) dukungan masyarkat dan orang tua siswa. Implementasi manajemen dalam peningkatan mutu pendidikan merupakan sebuah solusi nyata yang menjadi harapan agar dapat mengelola indikator mutu pendidikan untuk saling bersinergi dalam upaya peningkatan mutu pendidikan. (Muhammad Fadhli. 2017: 215).

Berdasarkan Kepemimpinan (Leading). Pembina Yayasan Pendidikan Thawalib Padang diketuai oleh Dr. H. Makmur Tizar, M.Ag, Kepala Umum Yayasan Pendidikan Thawalib Padang dibawah kepemimpinan ust. Azwir Ma'aruf,
M.A. Pimpinan pondok yang bernama Yasri Azmi,S.Th.I. Kepala Madrasah di kepalai oleh Drs. Dasrul, M.Pd. Kepala Tata Usaha bernama Taufik Hismar, S.Pd.I, Wakil Bidang Kurikulum bernama Drs. Mansur dan Wakil Bidang Kesiswaan bernama, Ikhwan Azmi, SE, M.Pd.E.

Dengan adanya kepemimpinan yang jelas dan terstruktur dengan baik menjadi lembaga pendidikan Pondok Pesantren Thawalib Padang ini berdiri sejak tahun 1985 dan eksis sampai sekarang sehingga melahirkan alumni yang siap bersaing dengan alumni yang lainnya. Dengan membentuknya pengkaderan yang kuat dan untuk menghindari beberapa permasalahan dan kelemahan yang terjadi di pesantren antara lain pertama, kebanyakan pesantren masih rigid (kaku) dengan mempertahankan pola salafiyah yang dianggapnya masih berupa sophisticated (ilmu-ilmu tasawuf) dalam menghadapi persoalan eksternal. Hal ini disebabkan antara lain pola kepemimpinan pesantren masih sentralistik dan hirarkhis yang terpusat pada satu orang kyai saja. Akibat yang paling fatal, jika kyai wafat dan tidak ada anak yang mau serta mampu mengurus pesantren yang dimilikinya, maka tak pelak pesantren tersebut akan redup. Kedua, kelemahan dibidang metodologi. Para ustadz maupun kyai sendiri kurang memiliki improvisasi dan inovasi dalam metode pengajarannya. (Daulay, 2001: 19).

$$
\text { Berdasarkan Pengendalian }
$$

(Controlling). Struktur organisasi yang baik akan selalu dievaluasi program kerjanya. Jika kinerjanya bagus bisa dipertahankan dan ditingkatkan. Jika rendah maka akan dilakukan pengajian dan pengevaluasian dari sudut kelemahan kekurangan organisasi tersebut. Oleh karena itu Yayasan akan melakukan pengawasan dan mengevaluasi terhadap kinerja staffnya, pimpinan pondok dan kepala madrasah. Pimpinan pondok akan melakukan pengawasan dan mengevaluasi terhadap kinerja pengasuhan santri dan walikamar serta pengurus OSTP (Organisasi Santri Thawalib Padang) 
terhadap seluruh aktivitas dan kegiatan yanga ada. Kepala madrasah akan melakukan pengawasan dan mengevaluasi terhadap kinerja staf beserta jajaran dan gurunya, yang berkaitan dengan proses pembelajaran yang ada pada jam pembelajaran madrasah. Kebijakan yang dikeluarga oleh kepada madrasah secara tidak lansung akan dikontrol oleh komite madrasah.

Hal tersebut bisa dilihat pada penerimaan murid baru yang terencana dengan baik, adanya sosialisasi dan prosedur penerimaan, pengorganisasian; terbentuknya kepanitiaan, pelaksanaan; verifikasi berkas, tes, dan pengawasan; pembinaan santri baru setelah dilakukan klasifikasi berdasarkan hasil tes. $\mathrm{Hal}$ tersebut, juga diimbangi dengan pengontrolan dan adanya evaluasi terhadap setiap kegiatan yang dilakukan.

Proses penerimaan santri baru berjalan cukup baik dengan adanya perencanaan; sosialisasi dan prosedur penerimaan, pengorganisasian; terbentuknya kepanitiaan, pelaksanaan; verifikasi berkas, tes, dan pengawasan; pembinaan santri baru setelah dilakukan klasifikasi berdasarkan hasil tes. Bimbingan santri dilakukan melalui kurikuler dan ektra kurikuler. Untuk mengembangkan bakat kepemimpinan, santri senior sangat terbantu adanya penunjukan kepanitiaan oleh ketua yayasan kepada santri senior setiap ada kegiatan pondok pesantren, walaupun organisasi santri belum terbentuk, (Saidi. 2016: vi).

Adanya pengendalian (controlling) yang jelas dan berkelanjutan dalam suatu organisasi atau lembaga pendidikan akan melahirkan luaran atau tamatan yang bermutu. Luaran atau tamatan yang bermutu akan menciptakan sumber daya manusia (SDM) yang berkualitas pula. Kualitas SDM ditentukan oleh mutu dan tingkat pendidikan. Kualitas pendidikan yang rendah menyebabkan kualitas SDM rendah; makin tinggi tingkat pendidikan maka makin tinggi pula kualitas SDM yang akan berpengaruh terhadap cara pikir, nalar, wawasan, keluasan dan kedalaman pengetahuan.(Yusutria, 2017: 38).

Hal tersebut sesuai dengan pemahaman manajemen menurut George R. Terry, yang diartikan sebagai proses khas yang terdiri dari tindakan-tindakan: perencanaan, pengorganisasian, penggerakan dan pengawasan yang dilakukan untuk menentukan serta mencapai sasaran-sasaran yang telah ditetapkan melalui pemanfaatan sumber daya manusia serta sumber-sumber lain. George R. Terry berpendapat bahwa manajemen merupakan ilmu sekaligus seni, yang definisinya adalah suatu wadah di dalam ilmu pengetahuan, sehingga manajemen bisa dibuktikan secara umum kebenarannya. (Yusuf, 2015: 21).

\section{Penerapan Fungsi Manajemen di} Pondok Pesantren Thawalib Padang Sumatera Barat Menghasil Mutu yang Berkualitas

Berkualitasnya out put/alumni yang dikeluarkan oleh lembaga pendidikan Pondok Pesantren Thawalib Padang berdasarkan dengan perencanaan dan pengambilan keputusan (planning), pengorganisasian (organizing), kepemimpinan (leading), dan pengendalian (controlling) yang baik dapat dilihat; Pertama; Tingginya tingkat kedisiplinan, cerdas, terampil dan berakhlak mulia dalam realita kehidupan para santri dan seluruh komponen pendukung yang ada dalam lingkungan sehari-hari. Kedua; Penguasaan dua bahasa bahasa Inggris dan bahasa Arab. Ketiga; Kematangan santrinya dalam berorganisasi yang sudah diajarkannya semenjak kelas IX tingkat Tsanawiyah. Keempat; Suksesnya para santri/murid dalam mengikuti berbagai perlombaan baik tingkat lokal, daerah maupun nasional seperti; pencak silat dan pramuka serta lomba tiga bahasa (bahasa Arab, Bahasa Inggris, dan bahasa Indonesia). Kelima; Secara kognitif, standar kelulusan yang ditentukan oleh negara, 
seluruh santri kelasa IX Tsanawiyah dinyatakan $100 \%$ lulusan ujian negara.

Dengan berkualitasnya sumber daya manusia (SDM) yang dimiliki oleh lembaga pendidikan Thawalib Padang ini, menjadikan lembaga tersebut pilihan bagi orangtua untuk memasukan anaknya kelembaga tersebut. Hal tersebut akan sesuai dengan tujuan pendidikan lembaga pesantren untuk membentuk manusia yang memiliki kesadaran tinggi dalam memahami ajaran Islam dengan membicarakan tiga masalah pokok, yaitu Tuhan, manusia dan alam setelah dikotomi mutlak antara Tuhan (khaliq) dengan makhluk, termasuk bentukbentuk hubungan antara ketiga unsur tersebut- yang bersifat menyeluruh. Selain itu produk pesantren diharapkan memiliki kompetensi tinggi untuk mengadakan responsif terhadap tantangan dan tuntutan hidup dalam konteks ruang dan waktu yang ada (Nurcholis Madjid, 1997: 18).

\section{KESIMPULAN}

Lembaga pendidikan Pondok Pesantren Thawalib Padang tersebut memainkan peran strategis bagi kemajuan umat dan bangsa dengan menerapak sistem pola manajemen dengan baik, hal tersebut bisa dipahami pada;

Berdasarkan perencanaan dan pengambilan keputusan (planning) dalam merumuskan visi, misi dan tujuan serta kurikulum yang jelas dan dicapai.

Berdasarkan pengorganisasian (organizing) yang telah memiliki struktur organsasi yang jelas mulai dari yayasan lembaga beserta jajarannya, pimpinan pesantren beserta jajarannya, sekolah beserta staff guru dan tenaga kependidikannya serta komite sekolah.

Berdasarkan kepemimpinan (leading) yang jelas. Hendaknya dalam kepemimpinan yang ada dalam lembaga pendidikan jangan sampai ada double fungsi atau rangkap jabatan. Agar mempermudah pengendalian dan pengontrolan.

\begin{abstract}
Berdasarkan pengendalian (controlling). Dilakukannya pengendalian/pengontrolan secara berkala. Hal tersebut dilakukan dengan tujuan bukan untuk mencari kesalahan/kekurangan akan tetapi demi untuk kebaikan kedepannya.
\end{abstract}

\section{DAFTAR PUSTAKA}

Aziz Amrullah. (2015). Peningkatan Mutu Pendidikan. Jurnal Studi Islam, Pancawahana. STAIN Pasuruan. Vol. 10, No. 2 Desember. pp. 2

Daulay. Haidar Putra. (2001). Historisitas dan eksistensi pesantren. Yogyakarta: Tiara Wacana. pp. 19

Depag RI. (2002). Pesantren Kilat. Jakarta: Proyek Peningkatan Pondok Pesantren. pp. 3

Depag RI. (2003). Pondok Pesantren dan Madrasah Diniyah. Jakarta: Direktorat Jenderal Kelembagaan Agama Islam. pp. 1

Ensiklopedi Ekonomi Bisnis dan Manajemen. (1992). Vol. 1, Jakarta: Cipta Adi Pustaka. pp. 374

Fadjar. A. Malik dkk., (1999). Reorientasi Pendidikan Islam, Jakarta: Fajar Dunia. pp. 21.

Fadli Muhammad. 2017. Manajemen Peningkatan Mutu Pendidikan. TADBIR: Jurnal Studi Manajemen Pendidikan. STAIN Curup Bengkulu | p-ISSN 2580-3581; eISSN 2580-5037 vol. 1, no 02. pp. 215-240.

Faisah. Sanipah. (1990). Penelitian Kualitatif; Dasar-dasar dan Aplikasi. Malang: YA3. pp. 22

K.. Soekarno,. (1965). Dasar-dasar Managemen, Jakarta: Firma Tekad. pp. $41-42$

Madjid. Nurcholis. (1997). Bilik-bilik pesantren. Jakarta: Paramadina. pp. 18 Mastuhu. (1994). Dinamika Sistem Pendidikan Pesantren. Jakarta: INS. pp. 55 
Masyhud, dkk. Sulthon (2003). Manajemen pondok pesantren. Jakarta: Diva Pustaka. pp. 14

Muradi (ed.), (2013). Penataan Kebijakan Keamanan Nasional, Jakarta: Dian Cipta, pp. 116.

Nur. Muhammad. Dkk. 2016. Manajemen Sekolah Dalam Meningkatkan Mutu Pendidikan Pada Sdn Dayah Guci Kabupaten Pidie. Jurnal Administrasi Pendidikan Pascasarjana Universitas Syiah Kuala. ISSN 2302-0156 Volume 4, No. 1, Februari. pp. 93 103.

Nurmadiansyah. M. Thoriq. (2016). Manajemen Pendidikan Pesantren: Suatu Upaya Memajukan Tradisi. Jurnal Membangun Profesionalisme Keilmuan, pp. 102

Qomar. Mujammil. (2007). Manajemen Pendidikan Islam: Strategi Baru Pengelolaan Lembaga Pendidikan Islam. Jakarta: Erlangga. pp. 11

Rodliyah. (2014). Manajemen Pondok Pesantren Berbasis Pendidikan Karakter (Studi Kasus di Pondok Pesantren "Annuriyyab" Kaliwining Kecamatan Rambipuji Kabupaten Jember). (Jurnal Cendekia, Vol. 12 No. 2, pp. 301).

Saidi. (2016). Manajemen Kesantrian Pada Pondok Pesantren Salafiyah Nurul Jannah Banjarmasin. Tesis. IAIN Antasari Banjarmasin. pp. vi

Turmudi. Endang. (2008). Pendidikan Islam Setelah Seabad Kebangkitan Nasional, dalam Jurnal Masyarakat Indonesia Majalab Ilmu-Ilmu Sosial Indonesia, Jilid XXXIV No. 2. pp. 78

Yusuf, Burhanuddin. (2015). Manajemen Sumber Daya Manusia. Jakarta: Rajawali Press. pp. 21

Yusutria, (2006). Persepsi Santri Terbadap Kemandirian Dalam Pendidikan Islam di Pondok Pesantren Thawalib Padang. Skripsi. IAIN Imam Bonjol Padang. pp. 1-25

Yusutria. (2012). Manajemen Strategis Pendidikan Islam; Studi Atas Konsep Manajemen Strategis. Makalah
Manajemen Strategis Pendidikan Islam, Pascasarjana (S3) IAIN Imam Bonjol Padang. pp. 2

Yusutria, (2017). Profesionalisme Guru Dalam Meningkatkan Kualitas Sumberdaya Manusia. Jurnal Curricula Kopertis Wil X. (Vol. 2, No. 1, pp. 38). 